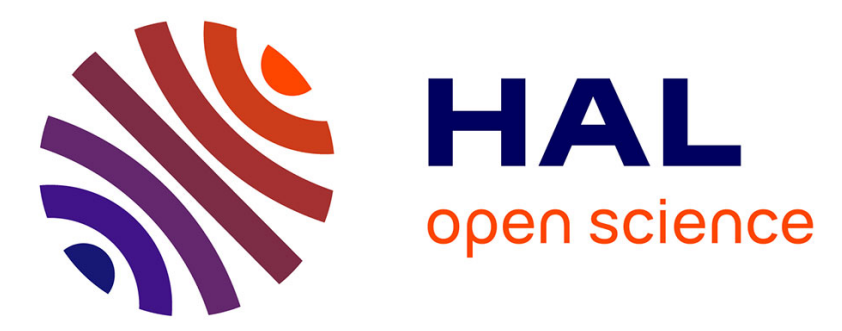

\title{
Low-temperature epitaxial growth of in-situ B-doped Si1-xGex films
}

J. Murota, F. Honma, T. Yoshida, K. Goto, T. Maeda, K. Aizawa, Y. Sawada

\section{To cite this version:}

J. Murota, F. Honma, T. Yoshida, K. Goto, T. Maeda, et al.. Low-temperature epitaxial growth of insitu B-doped Si1-xGex films. Journal de Physique IV Proceedings, 1993, 03 (C3), pp.C3-427-C3-432. 10.1051/jp4:1993359 . jpa-00251416

\section{HAL Id: jpa-00251416 https://hal.science/jpa-00251416}

Submitted on 1 Jan 1993

HAL is a multi-disciplinary open access archive for the deposit and dissemination of scientific research documents, whether they are published or not. The documents may come from teaching and research institutions in France or abroad, or from public or private research centers.
L'archive ouverte pluridisciplinaire HAL, est destinée au dépôt et à la diffusion de documents scientifiques de niveau recherche, publiés ou non, émanant des établissements d'enseignement et de recherche français ou étrangers, des laboratoires publics ou privés. 


\title{
Low-temperature epitaxial growth of in-situ B-doped $\mathrm{Si}_{1_{-x}} \mathrm{Ge}_{x}$ films
}

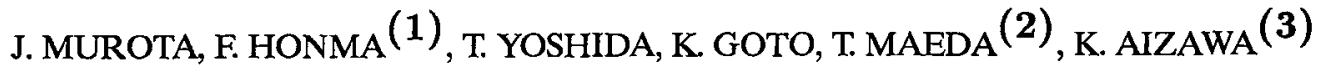 \\ and Y. SAWADA
}

Laboratory for Microelectronics, Research Institute of Electrical Communication, Tohoku University, 2-1-1 Katahira, Aoba-ku, Sendai 980, Japan

\begin{abstract}
We report in-situ boron doping of $\mathrm{Si}_{1-\mathrm{x}} \mathrm{Ge}_{\mathrm{X}}$ films epitaxially grown on Si(100) by low-pressure chemical vapour deposition (LPCVD) process. The experiments are performed in an ultraclean hot-wall system using ultra-pure $\mathrm{SiH}_{4}-\mathrm{GeH}_{4}-\mathrm{H}_{2}-\mathrm{B}_{2} \mathrm{H}_{6}$ gas mixtures. The incorporation rate of $\mathrm{B}$ was proportional to the $\mathrm{B}_{2} \mathrm{H}_{6}$ partial pressure and was larger for Ge-rich films. It was proposed that the increase in $B$ incorporation rate with increasing Ge fraction was caused by the larger surface adsorption rate of B-hydride on Ge atoms than on $\mathrm{Si}$ atoms. Since the incorporation rate of $\mathrm{B}$ increased with exposure time of $\mathrm{B}_{2} \mathrm{H}_{6}$ during $\mathrm{Si}_{1-\mathrm{x}} \mathrm{Ge}_{\mathrm{X}}$ deposition at early stage, it was suggested that $\mathrm{B}$ doping was limited by the $\mathrm{B}$-hydride adsorption rate. Hall measurements showed that garrier concentration was equal to $B$ concentration in the range $3 \times 10^{17}-2 \times 10^{20} \mathrm{~cm}^{-3}$, regardless of the Ge fraction, and Hall mobility passed through a minimum value for $\mathrm{Si}_{0.75} \mathrm{Ge}_{0.25}$ films regardless of the film thickness.
\end{abstract}

\section{1.-Introduction.}

The epitaxial growth of in-situ doped $\mathrm{Si}_{1-x} \mathrm{Ge}_{\mathrm{x}}$ films on $\mathrm{Si}$ at low-temperatures has become increasingly important for the fabrication of novel heterodevices $[1,2]$. Low-temperature LPCVD allows epitaxial growth of high quality $\mathrm{Si}_{1-\mathrm{x}} \mathrm{Ge}_{\mathrm{X}}$ layers [3-6] of various thicknesses and doping concentrations, e.g. abrupt steps in the doping profile, which is a key point for realizing devices with good performance. However, little is known about in-situ doping in heteroepitaxy of $\mathrm{Si}_{1-\mathrm{X}} \mathrm{Ge}_{\mathrm{X}}$ films on $\mathrm{Si}[7,8]$ and electrical characteristics of doped $\mathrm{Si}_{1-\mathrm{Ge}_{\mathrm{X}}}$ epitaxial films [9].

In the present work, in-situ $B$ doping of $\mathrm{Si}_{1-x} \mathrm{Ge}_{\mathrm{X}}$ films epitaxially grown on $\mathrm{Si}$ at $550^{\circ} \mathrm{C}$ and the relationship among resistivity, Hall mobility and carrier concentration for various $G$ fractions in $B$-doped $S i_{1-X} G_{X}$ film have been investigated.

\section{2. -Experimental.}

The epitaxial growth of in-situ B-doped $S i_{1-x} \mathrm{Ge}_{x}$ films was carried out at $550{ }^{\circ} \mathrm{C}$ in a $\mathrm{SiH}_{4}-\mathrm{GeH}_{4}-\mathrm{H}_{2}-\mathrm{B}_{2} \mathrm{H}_{6}$ gas mixture using an ultraclean hot-wall LPCVD system [10] (Figure 1). The LPCVD system was made ultrahigh vacuum compatible with gate valves and a turbo molecular pump system. The optimized deposition process sequence for high quality $\mathrm{Si}_{1-\mathrm{X}} \mathrm{Ge}_{\mathrm{X}}$ heteroepitaxial growth on $\mathrm{Si}$ using this system have been described in detail elsewhere [4-6]. In the present experiment, the deposition temperature was $550^{\circ} \mathrm{C}$ except for $\mathrm{B}$-doped Ge deposition at $350^{\circ} \mathrm{C}$ and $\mathrm{B}$-doped $\mathrm{Si}$ deposition at $650^{\circ} \mathrm{C}$. The total deposition pressure was about $30 \mathrm{~Pa}$, and the partial

(1) On leave from Miyagi OKI Electric Co., Ltd., 1 Okinodaira, Ohiramura, Kurokawagun, Miyagi 981-36, Japan

(2) On leave from Kokusai Electric Co., Ltd., Toyama Works, 2-1 Yasuuchi, Yatsuomachi, Neigun, Toyama 939-23, Japan

(3) On leave from Sumitomo Metal Mining Co., Ltd., Central Research Lab., Ichikawa 272, Japan 
pressures of $\mathrm{SiH}_{4}, \mathrm{GeH}_{4}$ and $\mathrm{B}_{2} \mathrm{H}_{6}$ were in the range 1.5-11.2, 5.0x10-2-6.0, and $1.25 \times 10^{-5}-1.25 \times 10^{4} \mathrm{~Pa}$, respectively. The film thicknesses range from 14 to $500 \mathrm{~nm}$. The substrates used were n-type $\mathrm{Si}$ wafers of 3-5 ohm-cm with mirror polished (100) surfaces. Before loading the wafers into the transfer chamber, they were cleaned in several cycles in a $4: 1$ solution of $\mathrm{H}_{2} \mathrm{SO}_{4}$ and $\mathrm{H}_{2} \mathrm{O}_{2}$, high-purity $\mathrm{DI}$ water, and $1 \% \mathrm{HF}$ with the final rinse in DI water.

The Ge fraction $x$ was estimated from the lattice constant of a thick relaxed $\mathrm{Si}_{1-\mathrm{Xe}} \mathrm{Gilm}$ deposited under the same conditions. The lattice parameter was determined by $\mathrm{x}$-ray diffraction. The $\mathrm{B}$ concentration in $\mathrm{Si}_{1-\mathrm{x}} \mathrm{Ge}_{\mathrm{X}}$ films was determined by secondary ion mass spectroscopy. The film thickness was measured by using a Tencor Alpha Step. The surface structure was evaluated by electron diffraction. To measure the carrier concentration and Hall mobility in $\mathrm{Si}_{1-\mathrm{X}} \mathrm{Ge}_{\mathrm{X}}$ films, a cloverleaf area of $\mathrm{Si}_{1-\mathrm{X}} \mathrm{Ge}_{\mathrm{X}}$ film on $\mathrm{Si}$ substrate was defined by photolithography and chemical etch, and the sheet resistivity and Hall coefficient were measured by the van der Pauw method at room temperature.

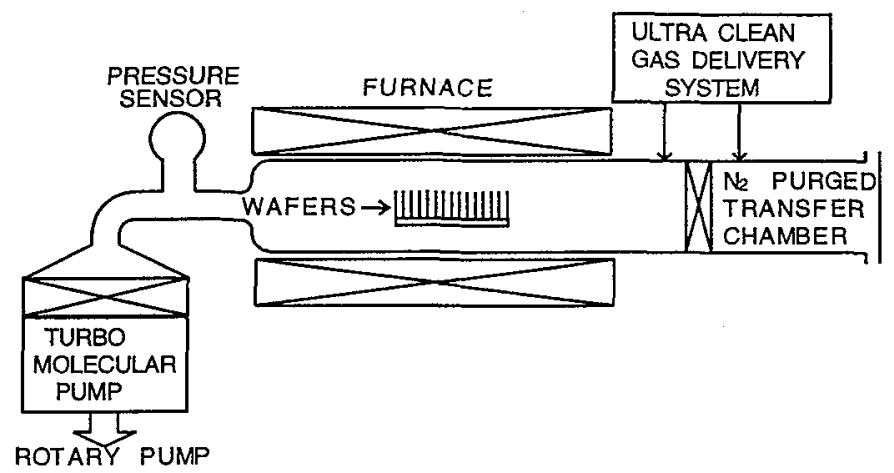

Fig.1.-Schematic diagram of the ultraclean hot-wall LPCVD system.

\section{3.-Results and discussion}

Figure 2 shows the dependence of $\mathrm{B}$ concentration in $\mathrm{Si}_{1-\mathrm{X}} \mathrm{Ge}_{\mathrm{X}}$ films on the $\mathrm{B}_{2} \mathrm{H}_{6}$ partial pressure. The $\mathrm{B}$ concentration is linear with $\mathrm{B}_{2} \mathrm{H}_{6}$ partial pressure. Deposition rate and $G e$ fraction $x$ of $\mathrm{Si}_{1-x} \mathrm{Ge}_{\mathrm{X}}$ films scarcely depend on the $\mathrm{B}_{2} \mathrm{H}_{6}$ partial

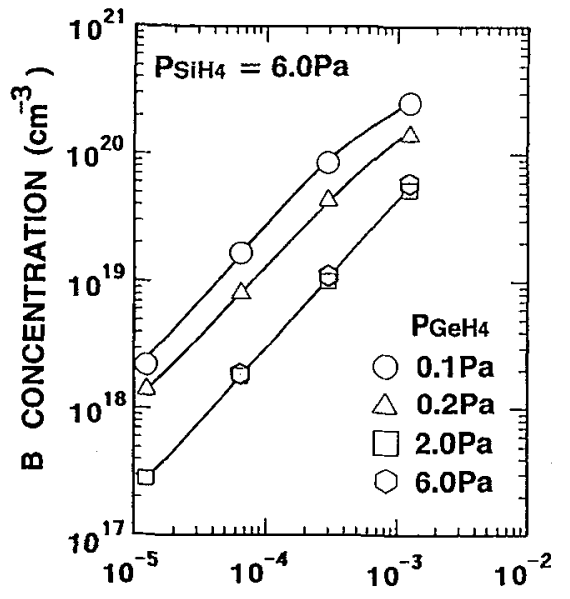

B2Hg PARTIAL PRESSURE (Pa)

Fig. 2. $-\mathrm{B}_{2} \mathrm{H}_{6}$ partial pressure dependence of $B$ concentration in $\mathrm{Si}_{1-\mathrm{X}} \mathrm{Ge}_{\mathrm{X}}$ films.

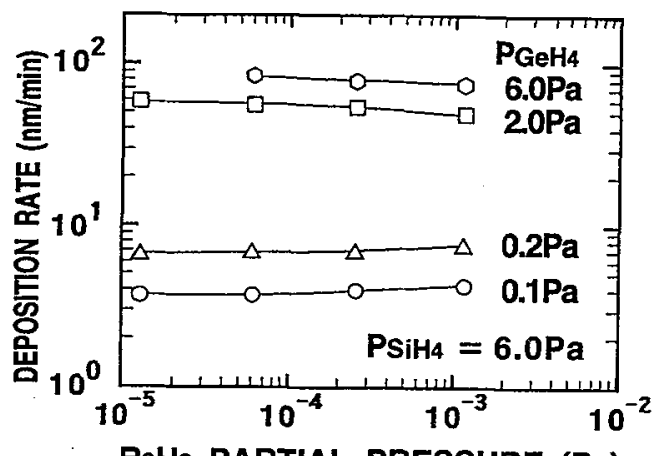

Fig. 3. $-\mathrm{B}_{2} \mathrm{H}_{6}$ partial pressure dependence of deposition rate of $S i_{1-X} G e_{X}$ films. 


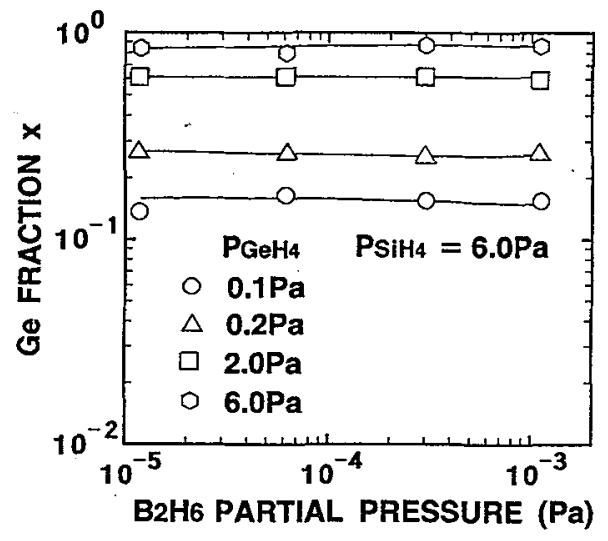

Fig.4. $-\mathrm{B}_{2} \mathrm{H}_{6}$ partial pressure dependence of $\mathrm{Ge}$ fraction in $\mathrm{Si}_{1-\mathrm{X}} \mathrm{Ge}_{\mathrm{X}}$ films.

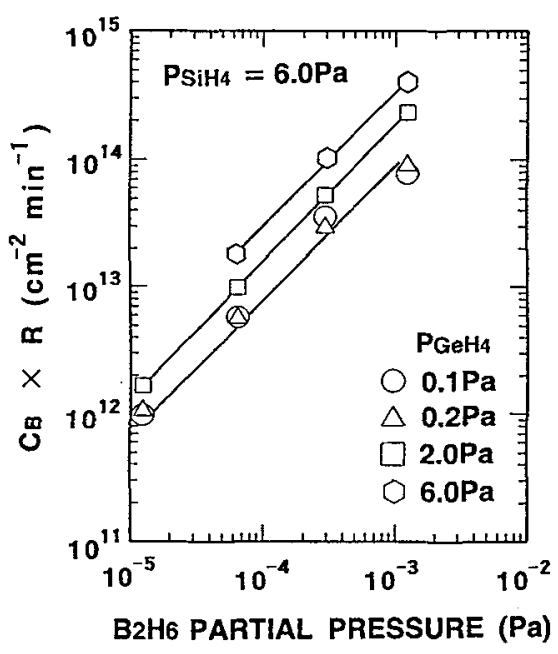

Fig.5. $-\mathrm{B}_{2} \mathrm{H}_{6}$ partial pressure dependence of $\mathrm{C}_{\mathrm{B}} \times \mathrm{R}$.

pressure as shown in Figures 3 and 4 . From Figures 2 and 3 , the dependence of $B$ incorporation rate, given by the product of the $B$ concentration $C_{B}$ and the deposition rate $\mathrm{R}$, on the $\mathrm{B}_{2} \mathrm{H}_{6}$ partial pressure is obtained as shown in Figure 5 . The incorporation rate of $\mathrm{B}$ is linear with the $\mathrm{B}_{2} \mathrm{H}_{6}$ partial pressure, and the slope increases with increasing the $\mathrm{GeH}_{4} / \mathrm{SiH}_{4}$ partial pressure ratio. This means that the incorporation rate of $B$ increases with increasing Ge fraction since the Ge fraction is determined by the $\mathrm{GeH}_{4} / \mathrm{SiH}_{4}$ partial pressure ratio [11]. Therefore, it is suggested that the incorporation of $\mathrm{B}$ into $\mathrm{Si}_{1-\mathrm{X}} \mathrm{Ge}_{\mathrm{X}}$ films is not limited by the mass-transport of $\mathrm{B}$-hydride in the gas phase, but is controlled by the surface reactions. Assuming that $\mathrm{B}_{2} \mathrm{H}_{6}$ molecules are decomposed completely into $\mathrm{BH}_{3}$ in the gas phase [12], it is considered that $\mathrm{BH}_{3}$ is adsorbed at adsorption sites on the deposited $\mathrm{Si}_{1-\mathrm{X}} \mathrm{Ge}_{\mathrm{X}}$ surface. It was reported that, for $\mathrm{Si}_{1-\mathrm{X}} \mathrm{Ge}_{\mathrm{X}}$ deposition in the $\mathrm{SiH}_{4}-\mathrm{GeH}_{4}$ gas mixture, $\mathrm{SiH}_{4}$ is dominantly adsorbed at adsorption sites based on a Langmuir adsorption isotherm under the same deposition conditions as in the present experiments [11]. However, at the $\mathrm{GeH}_{4} / \mathrm{SiH}_{4}$ partial pressure ratio of $1 / 30$, the incorporation rate of $\mathrm{B}$ into $\mathrm{Si}_{1-\mathrm{x}} \mathrm{Ge}_{\mathrm{X}}$ films was independent of the $\mathrm{SiH}_{4}$ partial pressure in the range 3.0-11.2Pa, although Si-hydride surface adsorption increases

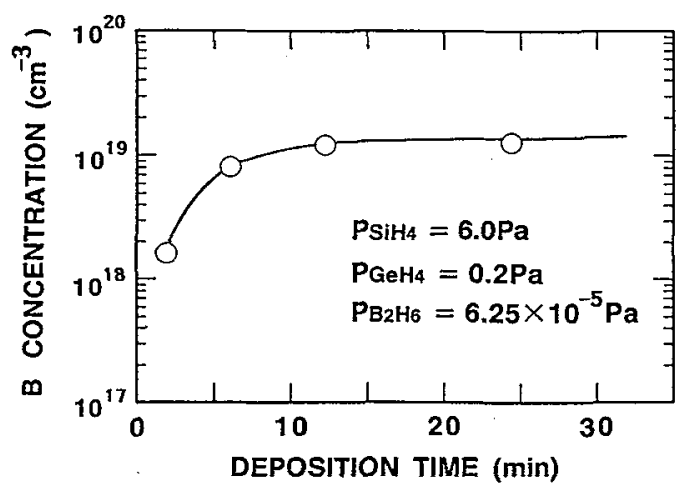

Fig.6.-Deposition time dependence of $B$ concentration in $\mathrm{Si}_{0.75} \mathrm{Ge}_{0.25}$ films.

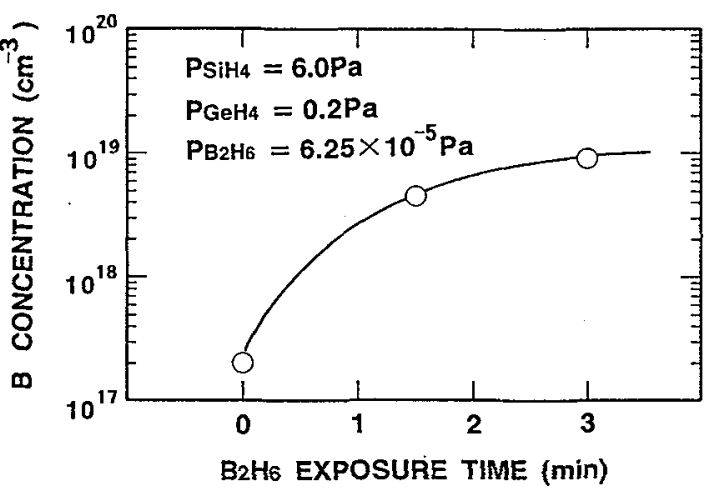

Fig.7.-Dependence of $B$ concentration in $\mathrm{Si}_{0.75} \mathrm{Ge}_{0.25}$ films on the $\mathrm{B}_{2} \mathrm{H}_{6}$ exposure time before film deposition. 
with increasing the $\mathrm{SiH}_{4}$ partial pressure. Therefore, it is proposed that Bhydride surface adsorption occurs regardless of Si-hydride surface adsorption, and as a result, the $B$ concentration in $\mathrm{SI}_{1-\mathrm{X}} \mathrm{Ge}_{\mathrm{X}}$ films is determined by the balance between the surface adsorption rate of $B$-hydride and the deposition rate. Based on this model, it is concluded that the increase in B incorporation rate with increasing $\mathrm{Ge}$ fraction is caused by the larger surface adsorption rate of B-hydride on $\mathrm{Ge}$ atoms than on Si atoms.

The deposition time dependence of $B$ concentration in $S_{0.75} \mathrm{Ge}_{0.25}$ films is shown in Figure 6. B concentration is lower at the early stage of the growth(thickness $\cong$ 14-46nm. It was confirmed that $\mathrm{Ge}$ fraction and deposition rate scarcely depend on film thickness [6]. By an increase in $\mathrm{B}_{2} \mathrm{H}_{6}$ exposure time before $\mathrm{Si}_{0.75} \mathrm{Ge}_{0.25}$ deposition, $B$ concentration at early stage increases and tends to becone nearly equal to that in the thicker film as shown in Figure 7 . Therefore, it is suggested that $B$ doping is limited by B-hydride adsorption rate at early stage. In other words, the time for reaching the surface adsorption equilibrium of B-hydride is longer than that of Si- and Ge-hydride.

The relationship between carrier and $B$ concentrations in the deposited $S i_{1-x} \mathrm{Ge}_{X}$ films is shown in Figure 8 . It is found that carrier concentration is equal to $B$

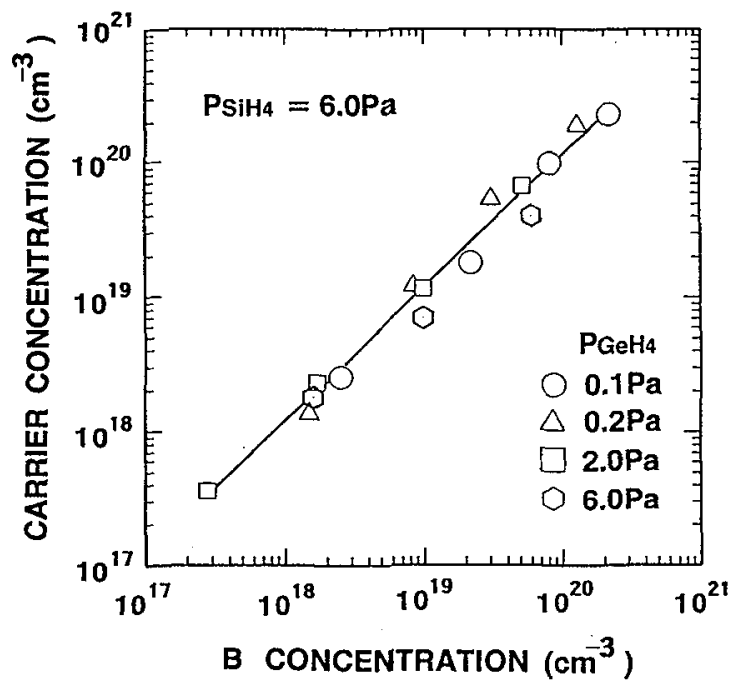

Fig.8.-Relationship between carrier and $B$ concentrations in $\mathrm{B}$-doped $\mathrm{Si}_{1-\mathrm{X}} \mathrm{Ge}_{\mathrm{X}}$ films.

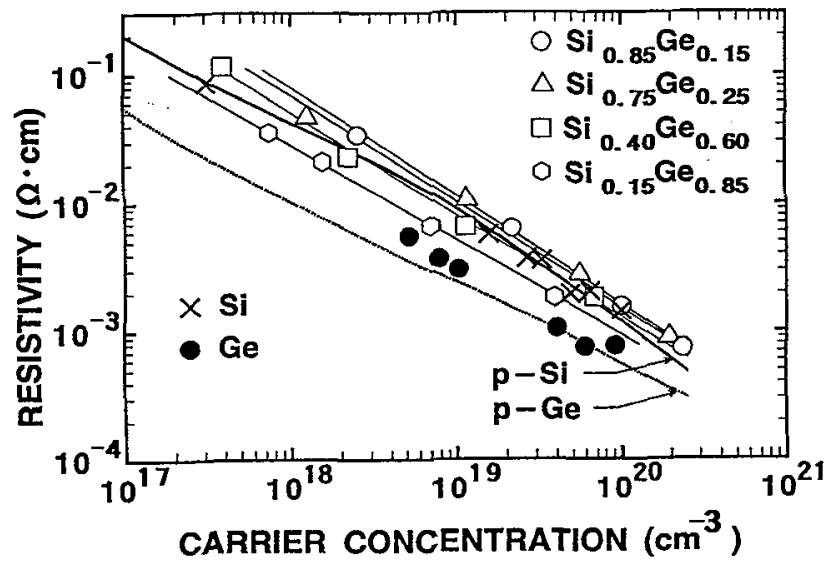

Fig.9.-Relationship between resistivity and carrier concentration in $\mathrm{B}$-doped $\mathrm{Si}_{1-\mathrm{X}} \mathrm{Ge}_{\mathrm{X}}$ films. Film thicknesses range from 200 to $500 \mathrm{~nm}$. 


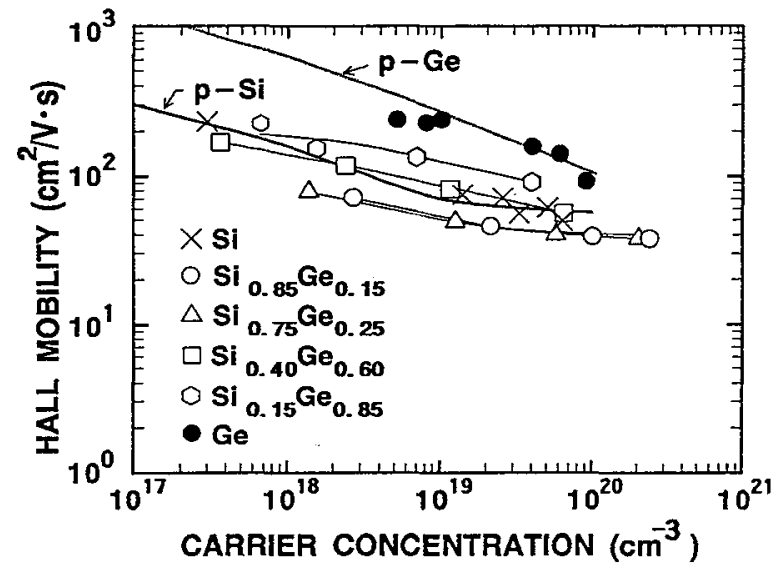

Fig.10.-Relationship between Hall mobility and carrier concentration in B-doped $\mathrm{Si}_{1-\mathrm{x}} \mathrm{Ge}_{\mathrm{x}}$ films. Hall mobility in $\mathrm{p}-\mathrm{Si}$ and $\mathrm{p}-\mathrm{Ge}$ according to references [13] and [14] are given by the solid lines. Film thicknesses range from 200 to $500 \mathrm{~nm}$.

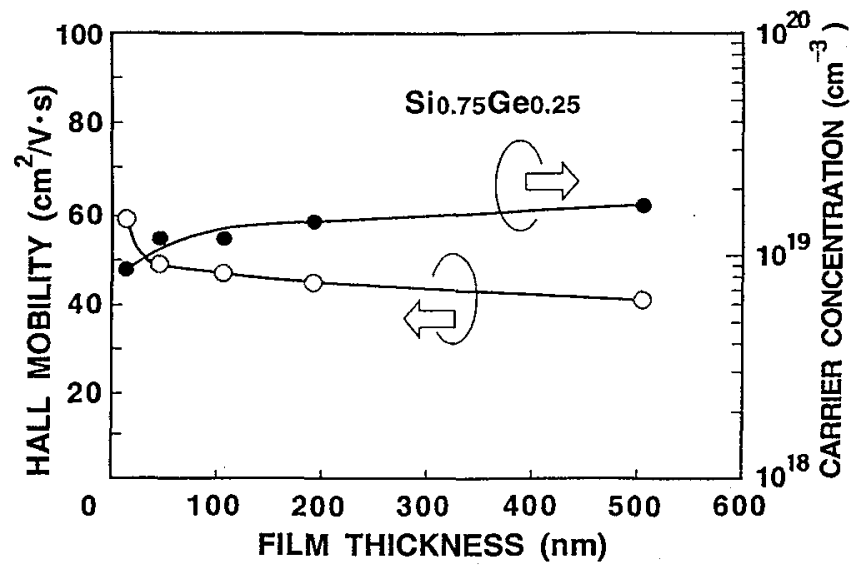

Fig.11.-Relationship among Hall mobility, carrier concentration and $\mathrm{Si}_{0.75} \mathrm{Ge}_{0.25}$ film thickness.

concentration in the range $3 \times 10^{17}-2 \times 10^{20} \mathrm{~cm}^{-3}$, regardless of the Ge fraction. In the present experiments, electron diffraction measurements showed that $B$ doped $\mathrm{Si}_{1-\mathrm{Xe}}$ films obtained were epitaxial. The relationship among resistivity, Hall mobility and carrier concentration for various Ge fraction is shown in Figures 9 and 10. Hall mobility exhibits a minimum value for $\mathrm{Si}_{0.75} \mathrm{Ge}_{0.25}$ films in $\mathrm{B}$ concentration below $10^{20} \mathrm{~cm}^{-3}$, whose value is lower than that observed in $\mathrm{Si}$, and then increases with Ge fraction. For Ge fraction of 0.25 , it is considered that Hall mobility is influenced by alloy scattering [9]. It should be noted that the Hall mobility in the present Ge and Si films is nearly equal to that in bulk $[13,14]$ as shown in Figure 10. The relationship among Hall mobility, carrier concentration and $\mathrm{Si}_{0.75} \mathrm{Ge}_{0,25}$ film thickness is shown in Figure 11. With increasing the thickness, Häll mobility decreases and carrier concentration increases. These data can be plotted on the line for $\mathrm{Si}_{0.75} \mathrm{Ge}_{0.25}$ films shown in Figure 10. It was confirmed that the current flow into substrate can be neglected in the present Hall measure- 
ments based on the result that sheet resistivity and Hall coefficient of $14 \mathrm{~nm}$-thick $\mathrm{Si}_{0.75} \mathrm{Ge}_{0.25} \mathrm{film}$ shown in Figure 11 were independent of current in the range $10^{-6}$ $2.5 \times 10^{-5}:$ From these results, Hall mobility would scarcely depend on the film thickness range 14-500nm if all the films of different thickness had the same carrier concentration. In other words, the mobility of the strained $\mathrm{Si}_{0.75} \mathrm{Ge}_{0.25}$ film is nearly equal to that of the unstrained one, since it is well known that the critical thickness for $\mathrm{SI}_{0.75} \mathrm{Ge}_{0.25}$ film grown on $\mathrm{Si}(100)$ is about $100 \mathrm{~nm}$ [15].

\section{4.-Conclusions .}

B-doped $\mathrm{Si}_{1-\mathrm{X}} \mathrm{Ge}_{\mathrm{X}}$ films have been epitaxially grown on $\mathrm{Si}(100)$ at $550^{\circ} \mathrm{C}$ by LPCVD. The incorporation rate of $\mathrm{B}$ increases proportionally with increasing $\mathrm{B}_{2} \mathrm{H}_{6}$ partial pressure and is larger on the deposited $\mathrm{Si}_{1-\mathrm{X}} \mathrm{Ge}_{\mathrm{X}}$ film with higher Ge fraction $\mathrm{x}$. It is proposed that the increase of $B$ incorporation rate with increasing Ge fraction is caused by a larger surface adsorption rate of B-hydride on Ge atoms than on $\mathrm{Si}$ atoms. Since the incorporation rate of $\mathrm{B}$ increased with exposure time of $\mathrm{B}_{2} \mathrm{H}_{6}$ during $\mathrm{SI}_{1-\mathrm{X}} \mathrm{Ge}_{\mathrm{X}}$ deposition at early stage, it is suggested that $\mathrm{B}$ doping is limited by B-hydride adsorption rate. In other words, time for reaching the surface adsorption equilibrium of B-hydride is longer than that of $\mathrm{Si}$ - and Ge-hydride.

Hall measurements show that the carrier concentration is nearly equal to $B$ concentration in the range $3 \times 10^{17}-2 \times 10^{20} \mathrm{~cm}^{-3}$, regardless of the Ge fraction, and Hall mobility has a minimum value for $\mathrm{Si}_{0.75} \mathrm{Ge}_{0.25} \mathrm{film}$, and the mobility of the strained $\mathrm{Si}_{0.75} \mathrm{Ge}_{0.25} \mathrm{film}$ is nearly equal to that of the unstrained one.

\section{Acknowledgments .}

The authors wish to express their thanks to Profs. Shoichi Ono and Takashi Matsuura for their advice and encouragement in executing this study. The CVD reactor was provided by Kokusai Electric Co. Ltd. This study was carried out in the Superclean Room of the Laboratory for Microelectronics, Research Institute of Electrical Comunication, Tohoku University, and was partially supported by Grant-in-Aid for Scientific Research from the Ministry of Education, Science, and Culture of Japan.

\section{References.}

[1] PATTON G. L., COMFORT J. H., MEYERSON B. S., CRABBÉ E. F., SCILLA G. J., FRÉSART E. D., STORK, J. M. C., SUN J. Y. C., HARAME D. L. and BURGHARTZ J. N., IEEE Electron Device Lett. EDL-11, (1990)171.

[2] STURM J. C., PRINZ E. J. and MAGEE C. W., IEEE Electron Device Lett. EDL-13, (1992) 56 .

[3] MEYERSON B. S., URAM K. C. and LEGOUES F. K., Appl.Phys.Lett. 53, (1988) 2555. Electron Device Lett. EDL-12, (1991) 154.

[4] MUROTA J., KATO M., KIRCHER R. and ONO S., J.Phys.IV France 1, (1991)C2-795

[5] SCHÜTZ R., MUROTA J., MAEDA T., KIRCHER R., YOKOO K. and ONO S., Appl.Phys . Lett. 61, (1992) 2674 .

[6] MUROTA J., MAEDA T, GOTO K., SAKAMOTO K., AIZAWA K., USHIODA S. and ONO S., J.Phys.IV France(this volume).

[7] TSAI C., JANG S.-M., TSAI J. and REIF R., J.Appl.Phys. 69, (1991) 8158.

[8] RACANELLI M. and GREVE D. W., J.Vac.Soc.Technol. B9, (1991) 2017.

[9] MANKU T. and NATHAN A., IEEE Trans. Electron Device, 39, (1992) 2082.

[10] MUROTA J., NAKAMURA N., KATO M., MIKOSHIBA N. and OHMI T., Appl.Phys.Lett. 54, (1989) 1007.

[11] KATO M. MUROTA J. and ONO S., J.Cryst.Growth 115, (1991)117.

[12] BAUER S. H., SHEPP A. and MCCOY R. E., J.Am.Chem.Soc. 78, (1956) 5775.

[13] TRUMBORE F. A. and TARTGLIA A. A., J.Appl.Phys. 29, (1958)1511.

[14] IRVIN J. C., Bell.Syst.Tech.J. 41, (1962)387.

[15] PEOPLE R. and BEAN J. C., Appl.Phys.Lett. B47, (1985) 322. 